\title{
Tomasz Grzegorz Grosse, Europa na rozdrożu, Instytut Spraw Publicznych, Warszawa 2008, ss. 486.
}

Przyjęcie 12 nowych państw, a także szereg nowych problemów politycznych i gospodarczych wymusiło debatę dotyczącą przyszłego kształtu unijnych instytucji i nowej wizji zjednoczonej Europy. Wielokrotnie stawiano pytanie, czy dotychczasowe rozwiązania wystarczą, by zapewnić jej dalsze, skuteczne funkejonowanie. Brakowało jednak wspólnej wizji Unii, aprobowanej przez wszystkie siły polityczne, a próby reform (Traktat lizboński) napotykały na poważne trudności i opór części państw członkowskich.

Tomasz G. Grosse jest ekspertem warszawskiego Instytutu Spraw Publicznych, specjalizuje się w problemach rozwoju regionalnego i w studiach europejskich. W swojej pracy Europa na rozdrożu, próbuje zmierzyć się z pytaniem o przyszłość integracji europejskiej. Grosse usiłuje przewidzieć kierunki rozwoju Unii Europejskiej po rozszerzeniu, oraz szanse realizacji poszczególnych koncepcji. Przedstawia również obszerny katalog wyzwań, którym musi sprostać zjednoczona Europa.

Jako pierwszy z problemów, Autor przedstawia konieczność dostosowywania się europejskich instytucji do realiów zglobalizowanej gospodarki światowej. Szeroko omawiając zmiany zachodzące na świecie wynikające z procesu globalizacji, analizuje on jego polityczne i gospodarcze konsekwencje dla zjednoczonej Europy. Stawia jednocześnie pytanie o rolę, jaką odgrywać może Europa we współczesnym świecie.

W następnej kolejności, Grosse podejmuje refleksję nad geopolitycznym znaczeniem Unii w XXI wieku. W swoich rozważaniach uwzględnia realistyczny paradygmat w stosunkach międzynarodowych, w myśl którego państwa i ich partykularne interesy nadal stanowią najważniejszy element światowej gry politycznej. Zgodnie z tym ujęciem, rozważa sytuację wewnętrzną Unii Europejskiej z punktu widzenia rywalizacji państw i równowagi sił na kontynencie. Autor przedstawia warianty uzyskania hegemonii w ramach Unii przez określone państwa (Niemcy), czy ich grupy (np. tandem niemiecko-francuski) oraz ewentualne niebezpieczeństwa, wynikające $\mathrm{z}$ takiej sytuacji.

Kolejnym poważnym problemem, któremu poświęca się w książce wiele uwagi, jest stopień legitymizacji unijnych instytucji. Mowa tu między innymi o deficycie procedur demokratycznych, zagrożeniach związanych $\mathrm{z}$ emancypacją brukselskich technokratów. Rozwiązaniem mogłaby być dalsza federalizacja Unii, jednak Autor uważa ten scenariusz za mało prawdopodobny. Zbyt silne są bowiem narodowe partykularyzmy, zwłaszcza wśród nowoprzyjętych państw, które dopiero od niedawna mogą cieszyć się pełną suwerennością.

Autor szczegółowej analizie poddaje również metody zarządzania stosowane w obrębie instytucji europejskich, przeciwstawiając sobie dwie główne koncepcje: technokratycznq i międzyrzqdowq. Zastanawia się również, w jakim kierunku ewoluować będzie europejski kapitalizm: czy w stronę liberalnych rozwiązań amerykańskich, czy raczej ku większej ingerencji państwa w gospodarkę. W swoich rozważaniach, Grosse analizuje poszczególne rozwiązania prawne i ich wpływ na kształt europejskiego rynku. Jednakże, mimo szeregu unijnych regulacji, w Europie funkcjonują nadal bardzo różne modele kapitalizmu i istnieje silny opór wobec prób unifikacji. Także w tym wypadku, Autor przedstawia wiele możliwych scenariuszy działania wraz z ich konsekwencjami.

Z podejściem do rynku i gospodarki nierozerwalnie związane są relacje pomiędzy pracodawcami a pracownikami. Tym samym w Europie na rozdrożu nie mogło zabraknąé miejsca dla kwestii dialogu społecznego. Wiele uwagi poświęcono próbom reform unijnych instytucji i dostosowania ich do zmian, które zaszły w wyniku rozszerzenia. Autor rozważa, czy jakakolwiek fundamentalna zmiana jest w ogóle możliwa. Zastanawia się również, który z modeli integracji zostanie ostatecznie wybrany: federacja demokratyczna, kondominium technokratyczne, czy konfederacja międzyrzqdowa. Aktualny kształt instytucji unijnych, Grosse określa jako roz- 
wiązanie hybrydowe, łączące elementy wszystkich powyższych modeli. Takie rozwiązanie charakteryzuje się - jak dotąd - dużą trwałością i nie jest podatne na zmiany. Jedynie swoisty przełom instytucjonalny mógłby przechylić szalę na korzyść jednego, konkretnego modelu.

Tomasz G. Grosse prezentuje szerokie spektrum problemów, z którymi musi zmierzyć się zjednoczona Europa. Przygląda się im z wielu różnych perspektyw teoretycznych, co pozwala na uzyskanie pełniejszego obrazu. W książce przedstawione zostało szereg potencjalnych rozwiązań. Grosse nie narzuca jednej, prostej odpowiedzi. Prezentuje różnorodność dróg, koncepcji i wariantów działania. Ta rozbudowana, szczegółowa analiza stanowi interesujący przyczynek do rozważań nad przyszłością integracji europejskiej oraz stojącymi przed nią szansami i zagrożeniami.

JAN PIOSIK

Poznań

\section{Parlament Europejski a sprawa Gazociagu Pótnocnego. Raport Marcina Libickiego. Biala Ksiega, red. Szymon Szynkowski vel Sęk, Poznań 2009, ss. 235.}

Problematyka bezpieczeństwa energetycznego oraz ochrony środowiska naturalnego są obecnie jednymi z kluczowych kwestii będących na agendzie Unii Europejskiej. Znaczenie tych spraw podkreśla fakt, iż są one wskazywane jako priorytety poszczególnych prezydencji w UE.

Recenzowana publikacja, nie jest publikacją naukową, a sprawozdaniem z procedowania określonego problemu przedstawionego Komisji Petycji Parlamentu Europejskiego, ale ważnego z wielu aspektów dla całej Unii Europejskiej. Bez wątpienia publikacja ma przede wszystkim na celu poinformowanie szerszej opinii publicznej o pracy Komisji Petycji i całego Parlamentu nad problematyką oceny oddziaływania na środowisko naturalne projektu gazociągu Nord Stream, jednakże nie można nie wskazać, iż z punktu widzenia Autorów ma ona także określone cele polityczne, na co wskazuje chociażby Słowo wstępne napisane przez Prezesa Prawa i Sprawiedliwości.

W pierwszej kolejność należy wskazać na tytuł publikacji. Pierwsza jego część wskazuje na fakt, iż przedstawia ona stanowisko PE w kontekście projektu, jakim jest budowa gazociagu Nord Stream. Druga część tytułu publikacji „,raport Marcina Libickiego” odnosi się w praktyce do Rezolucji Parlamentu Europejskiego z 8 lipca 2008 r. w sprawie wpływu planowanej budowy tzw. Gazociagu Północnego łączącego Rosję i Niemcy na środowisko naturalne Morza Bałtyckiego. Nie następuje zamieszczenie w publikacji dokumentu, który byłby podstawą przygotowania owej rezolucji, a co najwyżej wskazanie uzasadnienia Przewodniczącego Marcina Libickiego, co do konieczności przyjęcia rezolucji określonej treści. Największe zastanowienie budzi ostatnia część tytułu, gdyż w publikacji w zasadzie nie ma mowy o „Białej księdze”, a do tego należy pamiętać, że dokumenty o tej nazwie przygotowywane są przez Komisję Europejską.

Publikacja składa się z kilku części, których celem w znacznym stopniu jest wskazanie kontekstu, w którym sprawozdanie Parlamentu Europejskiego było tworzone oraz reakcji na ową rezolucję. Po pierwsze, są to informacje wprowadzające w kontekst przygotowania wskazanej rezolucji od momentu złożenia petycji do $\mathrm{PE}$, do zakończenia głosowania w Parlamencie, ze szczególnym zwróceniem uwagi na kwestie polityczne pojawiające się w tle przygotowania owej rezolucji, czyli wskazania na zaangażowanie lobbystów, którzy chcieli oddziaływać na treść raportu i rezolucji zgodnie $\mathrm{z}$ interesami spółki Nord Stream. Do tego podkreślone zostaje znaczenie tego projektu, jako przedsięwzięcia niemiecko-rosyjskiego. Bez wạtpienia część pierwsza ma charakter z przeważającym zakresie wypowiedzi o charakterze politycznym. 